\title{
Zpráva ze semináře Prezentace dějin v malých muzeích
}

Petr Chlebec

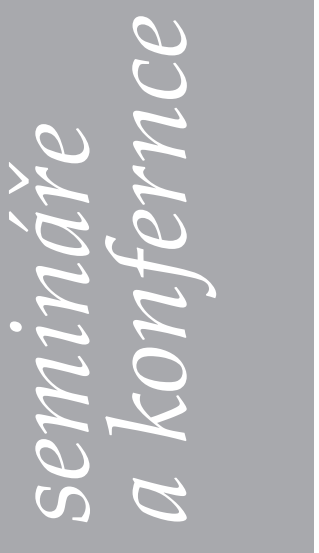

\section{Report from the seminar Presentation of History in Small Museums}

Abstract: The professional seminar Presentation of History in Small Museums was held on 23 and 24 September 2020 in Blatná. The aim of the seminar was not only to connect museum institutions, but also to present positive examples of the presentation of history in small museums. The theoretical and practical level of the presentation of history is important and its form is influenced not only by museum historians, but also by other professionals focusing on communication with the museum visitor. Individual thematic blocks focused on different views of the internal and external communication of the museum and the public.

Keywords: seminar, presentation of history, communication, regional museums

Prezentace dějin v muzeích, at’ už velkých či malých, představuje pro muzejní pracovníky výzvu s interdisciplinárním přesahem, nebot zde nehovoříme jen o akademické stránce historické vědy, archeologie či etnografie a jim př́ibuzných oborech, ale také o komunikačních prostředcích, muzejním publiku, pracovnících či zřizovatelích muzejních institucí. Název semináře naznačoval, že se bude jednat pouze o malá muzea, avšak přednesené referáty se dotýkaly českých muzeí jako celku, a to s ohledem na smysl muzeí, komunikační roviny či muzeí jakožto popularizátorů dějin ve veřejném prostoru.

Původním záměrem organizátorů z Komise muzejních historiků AMG ve spolupráci s Centrem kultury a vzdělávání Blatná bylo představit téma prezentace dějin $\mathrm{v}$ muzeu 7. a 8. dubna 2020. Vzhledem k propuknuvší epidemii onemocnění COVID-19 musela být akce přesunuta na 23. a 24. září. Bohužel zhoršující se situace nás pár dnů před seminářem donutila změnit formu akce, a to bez pasivních účastníků, abychom nezvyšovali riziko nákazy. Do Blatné přijeli jen referenti, kteří byli streamováni přes aplikaci Google Meet a zároveň natáčeni na videokameru. Video je nyní zveřejněné na odkazu www.ckvb.cz/muzeum/ seminar, kde jej mohou všichni zájemci zhlédnout a př́padně si stáhnout prezentace referentů.

Po úvodních slovech zahájil seminář svým referátem Mají malá muzea, zvláště ta vlastivědná v budoucnosti nárok na existenci? ředitel Západočeského muzea v Plzni PhDr. František Frýda. V úvodu se pokusil upřesnit své chápání pojmu „malé muzeum", který by nahradil označením vlastivědné muzeum. To by odráželo i účel muzeí, která hojně vznikala v 19. století pod vlivem Národopisné výstavy v Praze (1895). V muzeu byla tehdy archivována pamět' regionu či města $\mathrm{v}$ podobě hmotné kultury. Tuto činnost, stejně jako definici muzea, ovlivnily dějinné proměny, které ideologicky zasáhly do podoby paměti a její prezentace ve formě hmotné kultury. Mezi tyto mezníky zařadil vznik Československa v roce 1918, nástup komunismu v roce 1948 a také vznik zákona o muzeích a galeriích v roce 1959.

Po roce 1989, kdy na scénu prezentace dějin vstupují další média a volnočasové komerční instituce, se ještě více vytrácí účel muzea, které oproti nim vykonává svou činnost s posláním uchování paměti a prezentace pro studium, vzdělávání, výchovu a potěchu. Jistou míru odpovědnosti za vytrácení účelu muzea nese 
i zrrizovatel, který mnohdy klade důraz na materiální hodnoty a kulturní život zatlačuje do pozadí. Frýda neopomněl zmínit muzejní pracovníky, kteři často upadají do komerce $\mathrm{v}$ podobě vypůjčených výstav a počtu návštěvníků, čímž zároveň odpovídají na potřeby zřizovatele, nikoliv však veřejnosti.

Na konci referátu se vrací k prvotní otázce položené v názvu. Muzea jsou nositelem hmotné kultury se zaměřením na region. Jsou to jediné instituce uchovávající kulturu společnosti v menším geografickém či tematickém rozsahu, a proto díky nim přežívají specifika, která by jinak v globalizujícím se světě zanikla pod mainstreamovou kulturou, $-\mathrm{z}$ tohoto důvodu mají právě vlastivědná muzea smysl. Jejich existence závisí především na pracovnících muzeí, kteří musí svou činností přesvědčit veřejnost, a tedy i zřizovatele, o své nepostradatelnosti.

Ve zdánlivé návaznosti na nezodpovězenou otázku, jak by mohli muzejní pracovníci obhájit svou existenci v 21. století, vystoupila doc. Mgr. Petra Šobáňová, Ph.D. s referátem Muzejní prezentace jako edukační médium. Teze referátu vycházely z dvoudílné publikace Muzejní expozice jako edukační médium (2014), avšak ve zhuštěné formě, ve které byly vytyčeny hlavní body úspěšné prezentace zaměřené na komunikaci s návštěvníkem. Právě pro tento účel shledává referentka dưležitým propojení muzea a školy, a to ve formách prezentace, kdy jsou dějinné obrazy $\mathrm{v}$ muzeu na počátku příprav výstavy doplněny systematicky a plánovitě o interaktivně didaktické prvky. Výstava tak reaguje na potřeby návštěvníka, a to $\mathrm{v}$ různých formách s promyšleným cílem. Pro efektivní komunikaci muzea s návštěvníkem vytyčila deset bodů, jejichž pořadí však neurčuje jejich význam. Patří mezi ně přiměřenost předkládaných vjemů a informací; zpětná vazba ze strany návštěvníka, odborné veřejnosti, ale i pracovníků muzea a všech, kteří se podílí na výstavě; odbornost, která je většinou v muzeu dodržena na úkor srozumitelné komunikace; komplexnost rozvoje, jež nesmí být omezena dưrazem na vystavování

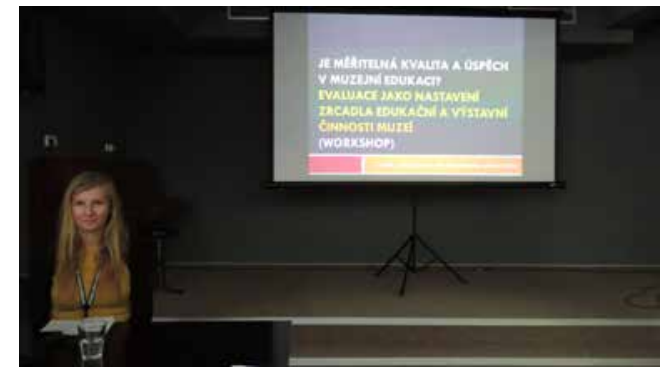

Druhý workshop Lucie Jagošové probihal ve vedlejším sále

sbírkových předmětů; propojení teorie a praxe; dávkování informací; emocionálnost a prožitek; názornost, ve které mohou muzea se sbírkami vynikat; a dialogické a kritické myšlení, kdy návštěvníkovi nejsou informace jen předkládány, ale je nucen se nad nimi zamyslet a konfrontovat zažité stereotypy s předkládaným obrazem. Velký př́nos vidí ve skrytém kurikulu, tedy významech prezentovaného obrazu "mezi řádky“.

Na závěr nabídla muzeím i možnost vybrat si témata absentující v nyněǰsím kolektivním povědomí, která by se odrazila v současných otázkách, jakými jsou např. migrace, nacionalismus nebo svoboda.

Právě tématu prezentace soudobých dějin, které nabízejí pestrou paletu dějinných obrazů dotýkajících se výrazně přítomnosti, se věnoval referát Mgr. Jakuba Jareše, Ph.D. Přednáška vycházela ze studie, jež je součástí souborné monografie Jak vystavujeme soudobé dějiny. Muzeum $v$ diskuzi (2020). Ke svému výzkumu prezentace soudobých dějin si vybral 24 muzeí. Na jejich př́kladu se pokusil určit jednotlivé formy prezentace soudobých dějin, které rozčlenil do pěti kategorií.

První z nich nazval Poznámka pod čarou, kdy soudobé dějiny jsou $\mathrm{v}$ expozici muzea uvedeny, avšak ve formě zhuštěného faktografického popisu nebo v obrazové formě v podobě fotografií po roce 1945. Druhou kategorii označil souhrnně jako Redukci na emblémy, kdy jsou soudobé dějiny regionu prezentovány jen na př́ikladu celostátních milníků jako např. rok 1945, 1948, 1968, 1989 atd. Třetí kategorii shrnul pod pojem Protetika. Dějiny 


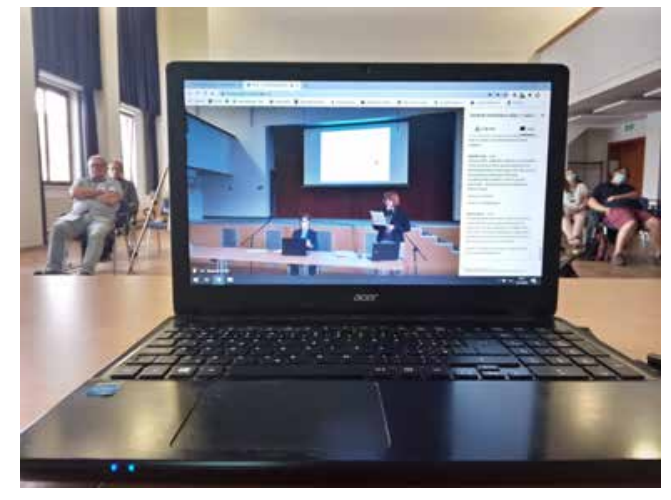

Online pos/uchači se zúčastnili diskuse skrze chat

regionu jsou zde nahrazeny celostátními či celosvětovými událostmi. Jako Tradiční učebnici označil referent expozice faktograficko-popisné, které nabízejí jen jednu perspektivu dějin objevující se ve školních učebnicích a nepřinášejí nic nového. Jako poslední uvedl kategorii Dobré muzeum, které poskytuje obraz soudobých dějin regionu s vlastní chronologií a geografickým vymezením. Jako př́klad vyzdvihl muzeum v Hlučíně, jenž představuje jedinečnost kraje, probouzí diskuzi a dialog s návštěvníkem a představuje i kontroverzní témata dějin. Takovou podobu by podle Jareše měla mít prezentace soudobých dějin regionu $\mathrm{v}$ muzeích.

Další blok semináře nazvaný Teoretická stránka dějin v muzeu zahájil Mgr. Petr Chlebec, který představil depozitáŕ malého muzea $\mathrm{v}$ trojím vidění muzejního historika. $\mathrm{K}$ členění do těchto zjednodušujících kategorií využil pojmy z historiografie - minulost, pamět a historie.

Minulost vnímanou jako objekt zájmu historické vědy, jako časový údaj nebo jako odraz zachycený $\mathrm{v}$ pramenech přirovnal ke sbírkovým předmětům, které byly v 19. století hojně vystavovány bez bližšího kontextu. Pamět představil jako cosi žitého a živého, což lze skloubit nejlépe s muzejními sbírkami ze soudobých dějin, nebo jako archivovanou jednotku kolektivní paměti regionu. Pamět je také nejpřitažlivější, nebơ je v ní přítomen člověk, jak v osobě historika, tak v návštěvníkovi. Vzhledem k zapomínání nezahrnuje nejstarší dějiny dál než ke stereotypưm. Pod pojem historie zahrnul odbornou stránku muzea, chápanou jako věda o minulosti nebo paměti. Kvůli odbornému jazyku není často přitažlivá pro běžného návštěvníka.

Pojítkem všech tří pojmů v muzeu je člověk. Historik při vstupu do depozitáře se nezaměřuje na prezentaci minulosti, paměti nebo odborné historie, ale na člověka. Ten se skrývá za každým předmětem jako jeho tvưrce, uživatel či dárce, je každému návštěvníkovi blíž a je obsažen i v autorech výstav a interpretátorech dějinného obrazu.

Následoval referát Mgr. Václava Sixty Dějiny ve veřejném prostoru, kterým poukázal na proměnu muzeí v posledních 50 letech. Tato změna šla ruku v ruce s proměnou kolektivní paměti či historického povědomí. Rámce, které výrazně ovlivňují dějiny ve veřejném prostoru, a tedy i v muzeu, shrnul do pěti bodů.

Globální turismus přinesl nejen využívání nových technologií, ale také nové otázky a dilemata nad prostory dějin, jako je např́klad koncentrační tábor v Osvětimi. $\mathrm{S}$ tímto rámcem souvisí i Kapitalismus tržního hospodářství, který přináší do světa muzea větší míru komerce, na které tyto instituce reagují. Další rámec nazval Demokratizace a digitalizace historie, tedy přenesení historie do virtuálního prostředí, do něhož vstoupila i muzea 21. století. Pojmem Muzealizace, vycházeje z knihy Memorylands od Sharon Macdonald, označil rámec, který představuje proces soukromého sběratelství a následného vystavování jako proměnu běžného předmětu v muzejní exponát. Tím se rozšiřuje skupina muzejních institucí o tyto často amatérské projekty. Poslední rámec nazval Školní dějepis a muzeum, dva fenomény, které se navzájem ovlivňují v edukačních programech a ve vzdělávacích projektech. Muzea 21. století se v těchto rámcích pohybují a nemohou zůstat izolovaně stát stranou. Je na těchto institucích, do jaké míry využijí jejich potenciál.

Další referentka Mgr. Monika Mikulášková představila pedagogický pohled na prezentace sbírkových předmětů a dějin 
v Muzeu Brněnska. Její referát vycházel z teorie učení a poznání od George Heina, který dělí edukaci na didakticko-výkladovou, formou objevování, prostřednictvím stimulu a reakce a konstruktivistickou. Je zjevné, že jako $\mathrm{v}$ předchozích př́kladech je pro nejefektivnější prezentaci dějin nutné propojit všechny čtyři edukační formy, avšak referentka poukázala na proces komunikace uvnitř muzea, který musí probíhat při př́ípravě výstavního projektu mezi pracovníky muzea např́ic všemi obory. Doslova všichni musí projít jednotlivými vrstvami učení, které jsou následně přeneseny na návštěvníka. Objektem prezentace může být i nevědomost a interpretace muzejních pracovníků. Základ pro efektivní komunikaci s návštěvníkem spatřuje Mikulášková $\mathrm{v}$ otevřenosti a komunikaci směrem k publiku i uvnitř tvưrčího týmu muzea.

Závěrečný př́spěvek bloku Animace, participace a další zaklínadla $v$ (městském) muzeu 2.0, 3.0, 4.0 představil Mgr. Zdeněk Duda, který vycházel z konceptu kultury a kulturního dědictví Piera Lugi Sacco. Takto rozčlenil muzeum nejprve do verze 1.0 jako chrám umění národa, státu či ideologie, jak bylo vnímáno $\mathrm{v}$ minulém století, a do verze 2.0, která se stala součástí zábavního průmyslu a edukace přirovnatelné k stavu českých muzeí po roce 1989. Následující verze 3.0 představuje dnešní cíle muzeí, jež se snaží stát místem společenského setkávání a inovací, kde se stírá hranice mezi autorem a publikem. Součástí této verze je také participace veřejnosti na prezentovaném dějinném obraze a inkluze. Poslední verze 4.0 predstavuje spíše plán do budoucna, který je ovlivněn digitalizací a proměnou pracovního trhu a průmyslu, čímž se mění i požadavky společnosti na muzeum.

Tento vnitřní obraz muzea Duda srovnává $s$ vnějším pohledem, jenž obsahuje mnohé stereotypy. Muzeum je představeno jako místo plné vitrín a předmětů, ale také zábavy. Právě ta je obsažena i v konceptu Národního muzea, kde má být zahájena éra "konce nudy v muzeu“. Společně s tím zaznívají v programu zmíněná hesla jako interaktivita, participace a animace. Autor se pozastavuje nad chápáním těchto pojmů ze strany českých muzeí. Rozumí se participací opravdu to, že se návštěvník zapojuje do tvorby expozice? Bývají v interaktivitě zohledněny didaktické prvky tak, aby sloužila ke kýžené edukaci? Oživuje či oduševňuje animace prezentovaný obraz dějin, a přispívá tak k upevňování sociálních svazků a zkvalitnění života? Pokud si na tyto otázky odpovíme ano, pak jsou tato muzea v českém prostředí na začátku, nebở vnější obraz stále odráží stereotypy verze $2.0 \mathrm{~s}$ menšími průniky prvků $\mathrm{z}$ verze 3.0. Mnohdy se $\mathrm{v}$ muzeích jedná o několik souběžných konceptů podléhajících módním trendům bez kontextu.

Závěrem si referent položil otázku co $\mathrm{s}$ tím. Samozřejmě se v muzeích musíme nadále vzdělávat a pochopit daná zaklínadla, jejich význam a aplikaci. Takto budeme schopni dát $\mathrm{v}$ muzeu větší prostor animaci a participaci, čímž se změníme v otevřený prostor pro dialog a setkávání reflektující i aktuální trendy a potřeby veřejnosti.

Poslední tematický blok Muzeum v roli popularizátora dějin představil tři expoziční a výstavní projekty od vize až $\mathrm{k}$ realizaci jako pozitivní př́íklady prezentace dějin v muzeích. Prvním byla výstava Oblastního muzea v Chomutově Únik z totality, kterou představila paní Miroslava Brúnová, DiS. Jako formu prezentace událostí z let 1988 a 1989 si zde vybrali únikovou hru, ve které mohl na malém prostoru tři místností koexistovat hráč i běžný návštěvník muzea. Muzejní publikum mohlo projít výstavu pasivně, avšak většina zvolila aktivní formu, která ve starším návštěvníkovi probouzela vzpomínky a nostalgii na hmotnou kulturu 80. let. Mladší návštěvník se aktivně propracoval postupným odhalováním problematiky ekologie a hornictví na Chomutovsku, které bylo spjaté s nespokojeností společnosti $\mathrm{s}$ režimem. To vedlo $\mathrm{v}$ prezentaci dějin $\mathrm{v}$ chomutovském muzeu až $\mathrm{k}$ událostem na Národní třídě a pádu komunismu.

Druhý referát ředitele Muzea Vysočiny Třebíč Ing. Jaroslava Martínka představil expozici obnoveného městského muzea 
Hrotovicka, na které se výrazně podílelo toto krajské muzeum. Poukázal na přerušenou kontinuitu muzejní instituce ve městě Hrotovice, která zde vznikla již v roce 1937, a to s velkým podílem sběratele a cestovatele Františka Bohuslava Zvěřiny. Muzeum zaniklo $\mathrm{v}$ roce 1962 a většina sbírek byla přenesena do Moravského zemského muzea v Brně a Západomoravského muzea $\mathrm{v}$ Třebíči. Právě část pozůstalosti zmíněného $F$. B. Zvěřiny přivedla město $\mathrm{k}$ činu a $\mathrm{v}$ roce 2004 otevřelo památník této osobnosti. Již tehdy pomáhalo při realizaci krajské Muzeum Vysočiny Třebíč.

$\mathrm{V}$ následujících letech se město rozhodlo zrekonstruovat staré stáje a rozšíríit dosavadní památník na muzeum celého Hrotovicka. Odborná informační linka regionu nového muzea vznikla dle dějin zpracovaných regionálním historikem Janem Suchardou a dětská linka včetně scénáře byla vypracovaná pracovníky muzea v Třebíči. Vznikla tak nová expozice prezentující regionální dějiny od pravěku po současnost, avšak s důrazem na regionální chronologii, kdy středověk je spojen s blízkou odkrytou vesnicí Mstěnice nebo období roku 1945 se sovětskou pumou shozenou na Hrotovice. Díky zapojení krajského muzea doplňuje tato expozice obraz regionu v síti ostatních muzeí, která prezentují odlišné stránky kultury v okrese Třebíć.

Přednáškový den zakončila Mgr. MgA. Iva Vachková, Ph.D. Představila tvorbu expozice Praha Karla IV. v domě U Zlatého prstenu, jejíž části byly otevřeny $\mathrm{v}$ letech 2016, 2017 a 2019. Téma stejně jako umístění expozice bylo vybráno pražským magistrátem. Muzeum se potýkalo s nedostatkem vhodných sbírkových předmětů, které by dostatečně srozumitelně prezentovaly obraz Prahy v době Karla IV., z toho důvodu využilo množství animací a multimediálních prvků vytvořených na míru. Referentka poukázala i na klady tvorby expozice po částech, kdy bylo možné poučit se $\mathrm{z}$ předchozích chyb. Výsledkem je efektní obraz proměny Prahy za Karla IV., který však skrývá i několik problematických momentů

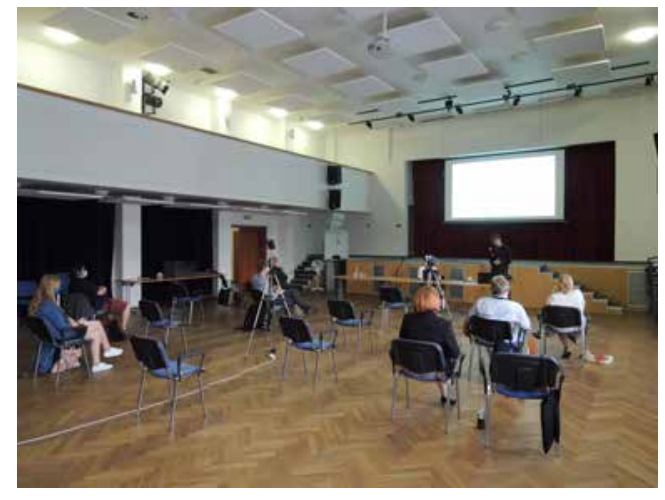

Sál Komunitního centra aktivního života v Blatné nám umožnil dodržet dostatečné rozestupy

v podobě rušivých imerzních prvků a zvuků a potemnělého prostředí nevhodného pro edukaci. $Z$ těchto důvodů vzniklo v domě U Zlatého prstenu odděleně dětské muzeum, ve kterém jsou obsaženy ony interaktivní didaktické prvky a participační nástroje. Expozice se bude i nadále vyvíjet a upravovat.

Seminář Prezentace dějin v malých muzeích představil několik zdánlivě různorodých tematických bloků. Pojítkem všech byl nejen optimismus a odhodlání pracovníků proměnit tvář českého muzejnictví, ale také se zde objevovala spojující linka v podobě komunikace. At́ již se hovořilo o prostředcích komunikace ve formě edukace nebo objektech zájmu nebo spíše nezájmu, kterému čelí soudobé dějiny, tak zde zazněla také nutnost porozumění v interní komunikaci a v užití jednotného pojmosloví a vidění prostředků muzejní prezentace dějin.

Druhý den semináře se nesl $\mathrm{v}$ duchu ryze praktickém. Bohužel i zde muselo dojít $\mathrm{k}$ redukci $\mathrm{z}$ důvodu epidemie. Uskutečněna byla jen exkurze do nově otevřené expozice Muzeum všemi smysly v Městském muzeu Blatná a dva paralelní workshopy. Jeden $\mathrm{z}$ nich vedl pan Mgr. Lukáš Faktor z Jihočeského muzea v Českých Budějovicích, který představil místní edukační kufř́ky. První tyto mobilní moduly vznikly právě $\mathrm{v}$ Jihočeském muzeu v Českých Budějovicích v roce 2016. Od počátku se jednalo o archeologické 
muzejní kufř́iky, které měly přenést hmotnou kulturu do rukou žáků a posluchačů ve školách i během edukačních programů v muzeích. Každý modul obsahuje také pracovní listy, které slouží žákům jako další vzdělávací materiály. Jejich obsah byl zároveň vytvořen se zohledněním RVP. Samozřejmě i zde došlo k různým praktickým ukázkám, zahrnujícím velikost či váhu mobilního kufř́íku, která do značné míry ovlivňovala jejich mobilitu.

Druhý workshop vedla paní Mgr. Lucie Jagošová. Zaměřila se na evaluaci, její odlišení od reflexe či jiných podobných forem zpětné vazby, které jsou v muzeu využívány jednotlivě a bez zjevného předem daného cíle. Zdůraznila mnohovrstevnatost evaluačního procesu, který kombinuje několikero zdrojů $\mathrm{z}$ vnějšího i vnitřního prostředí. Během workshopu jsme byli seznámeni s jakýmsi náčrtem př́pravy, procesem a závěrečným užitím evaluace jakožto komunikačního kanálu mezi muzeem a muzejním publikem. Díky takto získaným informacím může muzeum zapojit veřejnost do tvorby výstavních a expozičních projektů, a tak i docílit již dříve zmiňované participace a posílení sociálních a kulturních vazeb vedoucích ke zkvalitnění života společnosti. 